Gadjah Mada International Journal of Business

May 2002, Vol. 4, No. 2, pp. 149-175

\title{
PARADIGMS IN CONSUMER BEHAVIOR
}

\author{
Sabrina Oktoria Sihombing
}

A paradigm influences what we see and conceive about certain facts. Paradigm can also influence what we accept as a truth. Yet, the debate over which paradigm and methodology is best suit for marketing and consumer behavior has begun since 1980s. Many researchers criticized the domination of logical empiricism paradigm and offered alternative paradigm to understand marketing and consumer behavior.

This article discuss several paradigms and methodology, which are part of qualitative paradigm, and compares them with positivism paradigm. This article will also point to the importance of reconciliation between qualitative and quantitative paradigm in order to improve marketing and consumer behavior studies.

Keywords: alternative paradigms; methodologies; paradigm; positivism 


\section{Introduction}

There has been considerable debate on the appropriate philosophical and methodological foundations for consumer research since the early 1980s. The debate also centers on the truth that researchers desire to obtain. This debate was caused by the hegemonic position of logical empiricism in marketing and consumer behavior (Deshpande 1983). The friction arose because researchers who emphasize on quantitative approach (positivistics) often derogate other approaches as nonscientific (Levy 1996).

Furthermore, that domination paradigm, which is included in positive style of thinking (Nodoushani 2000) has been attacked by many researchers because the paradigm is perceived as paradigm that can block social sciences development. Furthermore, it is also perceived as an obstacle in developing high level social science theories (Soeroso 1984, cited by Wilardjo 1986). In relation with consumer behavior development, Smith and Lux (1983) stated that consumer behavior studies need many approaches in order to understand consumer behavior completely. In similar spirit with Smith and Lux, Deshpande (1983) pointed out that many style of thinking in both marketing and consumer behavior can support those two fields in developing new and rich explanatory theories.

There are many paradigms and methodologies have been offered by researchers, such as critical relativism (Anderson 1988)/cognitive relativism (Muncy and Fisk 1987), interpretativism/hermeneutic (Arnold and Fischer 1994; Spiggle 1994; Hudson and Ozanne 1988; Hirschman 1988; Holbrook and O'Shaughnessy 1988), humanistic inquiry (Stern and Schroeder 1993; Stern 1993; Stern 1989), existential and phenomenological methods [Thompson et al. (1994); Thompson (1990, 1989); Misiak and Sexton (1973)], ethnographic method (Fetterman 1989), historical method (Smith and Lux 1993; Fullerton 1988; Savitt 1980), critical theory (Murray and Ozanne 1991). Those paradigms and methodologies are paradigms and methodologies that can be classified as qualitative paradigm, that is, paradigms, which give emphasis to develop new theories rather than to test theories (Deshpande 1983).

The aim of this article is to describe several paradigms in consumer behavior, even though the description is not written in detail. The description includes comparison between each paradigm above with positivism. Therefore, this article aims to give understanding to the readers in order to obtain knowledge (i.e., advantages and disadvantages) of each paradigm. Furthermore, the aim of this article is also to describe qualitative methodologies in consumer behavior.

\section{Paradigm and Research Methodology}

Paradigm is a term introduced by Kuhn on his book The Structure of Scientific Revolution in 1962 (Ritzer 1992). In his book, Kuhn used the term paradigm 21 times in different ways. Furthermore, Robert Friedrichs was the first person who tried to define the concept 'paradigm', that is, paradigm is a perspective, which can be foundation for scientist about problems, and issues that should be studied in a branch of knowledge (Ritzer 1992).

Khun pointed out that there are several functions of the paradigm, for example: (1) paradigm as a guide for scientist in a discipline, for guiding them to clarify what are problems and issues in 
that discipline, (2) paradigm can help scientists to develop an explanatory scheme (i.e., models and theories) which can be used to solve problems, (3) paradigm helps scientist to establish the criteria for the appropriate tools (i.e., methodologies, instruments, types of data collection), and (4) paradigm provides an epistemology of the discipline (Filstead 1979, cited by Deshpande 1983).

Furthermore, Easterby et al. (1991) stated that there are three reason over the importance of understanding paradigm in a research design. Firstly, paradigm can help researchers to understand what is research design because research design itself is more than the method to collect and analyze data. It helps researchers to understand the overall configuration of a research, for example: what kind of data should be collected, and how such data is analyzed and interpreted in order to answer the research questions. Secondly, a paradigm helps researchers to understand and develop research design for his/her research. Lastly, it can help the researcher to identify and also to create research design that can be used if there are constraints in his/her research.

According to Evered and Louis (1981), paradigm can be classified into two types, which are inquiry from the outside' and 'inquiry from the inside'. On the other hand, Deshpande (1983) called those paradigms as quantitative paradigm and qualitative paradigm.

Evered and Louis (1981) pointed out that the differences between 'inquiry from the inside' and 'inquiry from the outside' are as follows: (1) researcher's role and relationship to the research setting, (2) the epistemological, and (3) the assumptions underlying the choice of role and relationship. For example, 'inquiry from the inside' emphasizes on researchers' understanding of an organization reality by being there. However, 'inquiry from the outside' emphasizes on the researcher's neutrality on the phenomena of study. Furthermore, the researcher is in the outside

Table 1. Differences between 'Inquiry from the Outside' and 'Inquiry from the Inside'

\begin{tabular}{|c|c|c|}
\hline Dimension of difference & From the Outside & From the Inside \\
\hline $\begin{array}{l}\text { Researcher's relationship to } \\
\text { setting }\end{array}$ & Detachment, neutrality & Being there," immersion \\
\hline Validation basis & Measurement and logic & Experiential \\
\hline Researcher's role & Onlooker & Actor \\
\hline Source of categories & A priori & Interactively emergent \\
\hline Aim of inquiry & $\begin{array}{l}\text { Universality and } \\
\text { generalizability }\end{array}$ & Situational relevance \\
\hline $\begin{array}{l}\text { Types of knowledge } \\
\text { acquired }\end{array}$ & $\begin{array}{l}\text { Universal, homothetic: } \\
\text { theory }\end{array}$ & $\begin{array}{l}\text { Particular, idiographic: } \\
\text { praxis }\end{array}$ \\
\hline Nature of data and meaning & Factual, context free & $\begin{array}{l}\text { Interpreted, contextually } \\
\text { embedded }\end{array}$ \\
\hline
\end{tabular}

Source: Evered and Louis (1981: 389) 
of the phenomena. The differences between those inquiries are summarized in Table 1.

In a similar spirit with Evered and Louis, Deshpande (1983) also pointed out that the characteristic differences of qualitative and quantitative paradigms are in their methodologies (Table 2). As Khun (cited by Deshpande 1983) pointed out that the link between paradigm and research methods is very strong. In particular, paradigm helps to establish the criteria for the appropriate tools (i.e., methodologies, instruments, types of data collection) for investigating the phenomena of study. Table 2 shows the major characteristics of each paradigm. The table shows, for example that quantitative paradigm prefers quantitative methods and the researcher seeks causes of phenomena without advo- cating subjective interpretation. On the other hand, qualitative paradigm uses qualitative methods and the researcher concerns with causes of phenomena from his/ her frame of reference.

As mentioned before, the aim of this article is to describe paradigms and methodologies in consumer research. This article uses the term qualitative paradigm and quantitative paradigm and not the term 'inquiry from the inside' and 'inquiry from the outside' because the term qualitative and quantitative paradigms are widely used in many disciplines. The term 'paradigm' is used interchangeable with the term 'philosophy' and 'style of thinking'. This article starts with description of positivism and followed by description of qualitative paradigms. The importance of reconciliation between quantitative and qualitative

\section{Table 2. Characteristics of Qualitative and Quantitative Paradigms}

\begin{tabular}{lll}
\hline \multicolumn{1}{c}{ Qualitative Paradigm } & & \multicolumn{1}{c}{ Quantitave Paradigm } \\
$\begin{array}{l}\text { Qualitative methods preferred } \\
\text { Concerned with understanding human } \\
\text { reference }\end{array}$ & & $\begin{array}{l}\text { Quantitative methods preferred } \\
\text { Seeks the facts or causes of social pheno- } \\
\text { mena without advocating subjective in- } \\
\text { terpretation }\end{array}$ \\
$\begin{array}{l}\text { Phenomenological approach } \\
\text { Uncontrolled, naturalistic observational } \\
\text { measurement. }\end{array}$ & $\begin{array}{l}\text { Logical-positivistic approach } \\
\text { Obtrusive, controlled measurement }\end{array}$ \\
$\begin{array}{l}\text { Subjective; "insider's perspective;" } \\
\text { close to the data }\end{array}$ & $\begin{array}{l}\text { Objective; "outsider's perspective;" } \\
\text { distanced from the data }\end{array}$ \\
$\begin{array}{l}\text { Grounded, discovery-oriented, explora- } \\
\text { tory, expansionist, descriptive, inductive }\end{array}$ & $\begin{array}{l}\text { Ungrounded, verification-oriented, con- } \\
\text { firmatory, reductionist, inferential, } \\
\text { hypothetic-deductive }\end{array}$ \\
Process-oriented & & Outcome-oriented \\
Validity is critical; "real"; "rich"; and & $\begin{array}{l}\text { Reliability is critical, "hard" and } \\
\text { "deep" data }\end{array}$ & "replicable" data \\
Holistic - attempts to synthesize & Particularistics - attempts to analyze \\
\hline
\end{tabular}

Source: Deshpande (1983: 103) 
Oktoria Sihombing_Paradigms in Consumer Behavior

paradigms to develop consumer behavior science is also presented.

\section{Quantitative Paradigm}

\section{Positivism}

The $19^{\text {th }}$ century is known as the positivism century. It can be recognized through the spirit of enlighten and antimetaphysics. In particular, the separation between metaphysics and rational was declared in that century. That separation was translated by rejecting the dogma 'a dualist way of knowing', that is, nature versus society. Furthermore, the scientific conception of the world was the goal of the positivism century (Nodoushani 2000).

Positivism century was closely associated with the philosopher Auguste Comte (1798-1857) who introduced three stages of development: (1) the theological, (2) the metaphysical, and (3) the positive (Wibisono 1982). Those three stages can be explained as follows. In the first stage (i.e., theological stage), all events are caused by the will of God. Furthermore, abstract concepts, such as 'essence', replace the will of God in the metaphysical stage. In the final stage, the discipline gives up the quest for absolute knowledge in the sense of 'final will' or 'final cause,' and instead, turns toward attempting to discover law like relationships of coexistence and succession by using scientific methods (Hunt 1991).

According to Comte, there are five meanings of the concept of positivist. First, positive is the opposite of illusion. Positive means something real that can be obtained by human thought. Second, positive is the opposite of uselessness. Positive means something useful that can help humankind to obtain knowledge. Third, positive is the opposite of doubtfulness. Posi- tive means something definite and logic. Fourth, positive is the opposite of something indistinct. Positive means something that can give understanding clearly and completely. Fifth, positive is the opposite of negative. Positive means movement toward faultlessness (Wibisono 1982).

The term positivism arose in $20^{\text {th }}$ century, was known as logical positivism (Wibisono 1982) or also can be called as neopositivism (Delfgauw 1988). Logical positivism links the empirical tradition with logic. In other words, philosophy is based on experience and logic (Delfgauw 1988).

As mentioned before, nonpositivistic paradigm will be compared with positivistic paradigm. Positivism terminology includes empiricism and realism (Kavanagh 1994). Nonpositivistic paradigms include relativism; interpretativism, humanism, existential, phenomenology, critical theory, and their methodologies will be presented. The assessment of positivism (i.e., advantages and disadvantages) will be pointed out before nonpositivist paradigms are compared with positivism.

\section{Positivism advantages}

u Positivism supports positivistic methodologies, that is, methodologies that emphasize on positive knowledge that does not contain speculative elements (Wibisono 1982). In other words, this paradigm tries to rationalize by disenchanting humankind from metaphysics through the scientific revolution (Nodoushani 2000).

u Methodologies used by positivistic center on careful sampling, sophisticated designs, precise measurement, and careful analysis in the hypothesis testing (Nodoushani 2000). By using the quantitative methods, the main strengths are as follows: (1) they can provide wide 
coverage of the range of situations, (2) they can be fast and economical, and (3) they can be used for policy decisions especially when statistics are aggregated from large samples (Easterby et al. 1991).

$\mathrm{u}$ The positivist paradigm supports the creativity spirit and action in obtaining facts and predicting the future (Wibisono 1982).

\section{Positivism Disadvantages}

$\mathrm{u}$ The paradigm centers knowledge as the only science that can obtain the truth. Therefore, this paradigm can reduce humankind and nature objects. In other words, this style of thinking only sees humankind as an object of reality, not the humankind subjectivity, such as experiences and humankind life (Wibisono 1982). In similar addition, Wilardjo (1986: 326, emphasis added) also stated as follows:

Human actions always consist of meaning and those actions have goals. Physics approach cannot be applied because of social facts are always express mentality condition, such as beliefs, hopes, and awareness. This thinking condition cannot be observed.

$\mathrm{u}$ Positivism can not explained humankind histories, especially about the way of human thought and the rise of a perspective. Also, this paradigm cannot include the truth of humankind, that is, humankind is the complete body, which consists of many chemical elements, and also humankind has elements (i.e., thought, will, feel) that each element cannot be reduced (Wibisono 1982).

$\mathrm{u}$ Beside humankind, there are other things in nature such as physics. Neutron in physics cannot be observed directly (Wilardjo 1986). $\mathrm{u}$ Positivistic methodologies are often concerned with whether empirical data fits a theory, or vice versa. Then, they usually test a theory against data. That procedure is known as a null hypothesis testing. However, the null hypothesis testing has dysfunctional consequences, for example, it makes the researcher's attention only on obtaining statistical significance rather than try to find the strength of the relationship which is more relevant and useful (Olson 1983).

$\mathrm{u}$ The null hypothesis testing also has disadvantages, such as researcher uses statistical inference analyses and let the data 'speak for themselves'. Furthermore, the null hypothesis testing does not tend to generate the conceptual speculations that are necessary in modifying and improving theories (Olson 1983).

$\mathrm{u}$ The use of quantitative methods tends to be rather inflexible and artificial. In particular, the use of that method is not very effective in understanding process of human actions. Furthermore, quantitative methods are not very helpful in generating theories (Easterby et al. 1991).

$\mathrm{u}$ The danger of positivism is showed by Feyerabend (1980, quoted by Nodousahni 2000: 76 ) as follows:

...the danger of positivism is in denying access to control the evaluation of scientific research through democratic means - i.e., using the standards of the tradition to which every democratic assembly of citizens belong in a free society. In this respect, a science that insists on possessing the only correct method and the only acceptable results is an ideology and must be separated from the state and especially education. 


\section{Qualitative Paradigm}

\section{Relativism}

Relativism can be traced back to the time of Socrates (470-399 BC), particularly about his debate with Protagoras about the relativistic truth. Relativism, that is proposed by Protagoras, is relativism with its doctrine that stated man is the measure of all things. In other words, what is right for someone is not always right for others (Ekelund and Herbert 1997).

Relativistism can also be understood from the work of Kuhn. Kuhn introduced the concept of incommensurability. The concept implies that (1) the knowledgeclaims of a paradigm are relative to that conceptual framework, and (2) they cannot be objectively evaluated across rival paradigms. The major thesis of Kuhnian relativism is the concept of 'incommensurability', which caused by the inability to adjudicate paradigm choice because the lack of any required degree of precision (Hunt 1991a).
Another relativistic philosopher is Feyerabend. He is an exuberant relativist (Hunt 1991a). In his book, Against Meth$o d s$, he stated that science is not rulegoverned endeavor. In other words, general rules for all science was illusion that only be as a hindrance rather than a help. Therefore, a person trying to solve a problem, whether in science or outside science, should be given a freedom to handle that problem without being restricted by any rules or norms (Hunt 1991a).

Anderson (1983, cited by Hunt 1991a) was one of the relativism supporters in 1980s. According to him, science can be defined into two different meanings (i.e., science $_{1}$ and science $_{2}$ ). Science is defined $_{1}$ as a system that can produce objectively proven knowledge. On the other hand, science $_{2}$ can be defined as whatever society chooses to call a science. Anderson proposed that marketing should adopt science $_{2}$ because the appropriate criterion to evaluate marketing theory is the usefulness and not the truth (Hunt 1991a).

\section{Figure 1. Relativistic View of Reality}

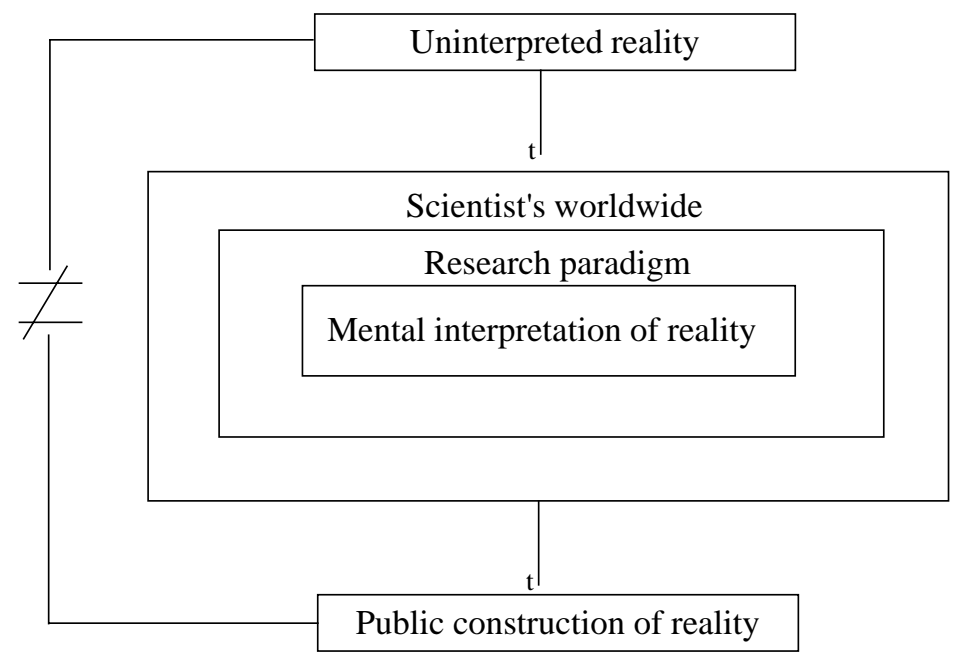

Source: Peter (1992: 74) 
GadjahMadaInternationalJournal ofBusiness,May2002, Vol.4,No.2

Table 3. Positivism versus Relativism

Positivism
Science discovers the true nature of
reality
Only the logic of justification is needed
to understand science
Science can be understood without
considering cultural, social, political and
economic factors

economic factors

Science is objective

Scientific knowledge is absolute and cumulative

Science is capable of discovering universal laws that govern the external world

Science produces theories that come closer and closer to absolute truth

Science is rational since it follows rules of formal logic

There are specific procedures for doing good science (e.g., falsification)

Scientist subjects their theories to potential falsifation through rigorous empirical testing.

Measurement procedures do not influence what is measured

Data provide objective, independent benchmarks for hypothesis testing

Relativism

Science creates many realities

The processes by which theories are created, justified and diffused throughout a research community are needed to understand science

Science is a social process and cannot be understood without considering cultural, social, political, and economic factors

Science is subjective

Scientific knowledge is relative to a particular context and period of time in history

Science creates ideas that are context dependent, i.e., relative to a frame of reference

Truth is a subjective evaluation that cannot be properly inferred outside of the context provided by the theory

Science is rational to the degree that it seeks to improve individual and societal well being by following whatever means are useful for doing so

There are many ways of doing science validly that are appropriate in different situations

Scientists see supportive, confirmatory evidence in order to market their theories

Nothing can be measured without changing it

Data are created and interpreted by scientist in terms of a variety of theories and thus are theory laden

Source: Hunt (1991: 408-409) 
From arguments that have been pointed out by several scientist (i.e., Kuhn, Feyerabend, and Anderson), the characteristics of relativistics can be summarized, as can be seen below. Then, Table 3 shows the differences between positivism and relativism.

$\mathrm{u}$ Science is a social process.

$\mathrm{u}$ Relativistics stated that science is subjective. Therefore, it always possible that error may happen in an observation.

$\mathrm{u}$ Relativistics hold the perspective that there is no interpretation of phenomena of interest can be made without human perceptions, feelings, sensations, and actions (see Figure 1).

$\mathrm{u}$ Relativistics pointed out that there is no single unique scientific method.

$\mathrm{u}$ Relativistics reject the claim that stated empirical testing provides better reasons to choose the knowledge-claims of medical science over palmistry.

\section{Hermeneutic/Interpretive}

Social sciences and especially consumer behavior are related closely with human problems. One major human characteristic is their tendency to seek meaning in their lives. In search of meanings, the humanities uses an approach often referred to as 'interpretive'. That approach helps to determine motives, meanings, reasons and other subjective experiences. Interpretation itself can be defined as the critical analysis of a text for determining its single or multiple meaning(s) (Holbrokk and O'Shaughnessy 1988).

Interpretive paradigm, or some scientist call hermeneutic paradigm, is also a specific philosophical program that has provided a theoretical foundation for many genres of social science research following in the spirit of linguistic turn (Thompson 1997:439). In particular, the paradigm emphasizes that all understanding is linguistic (Arnold and Fischer 1994). In relation with marketing and consumer behavior, Thompson (1997) pointed out that paradigm can contribute to create understanding on how consumers interpret their needs and desires on product and service. Therefore, 'the voice of the customer' can be placed at the center of an integrated marketing approach.

Figure 2. A Hermeneutic Model of Meaning Construction

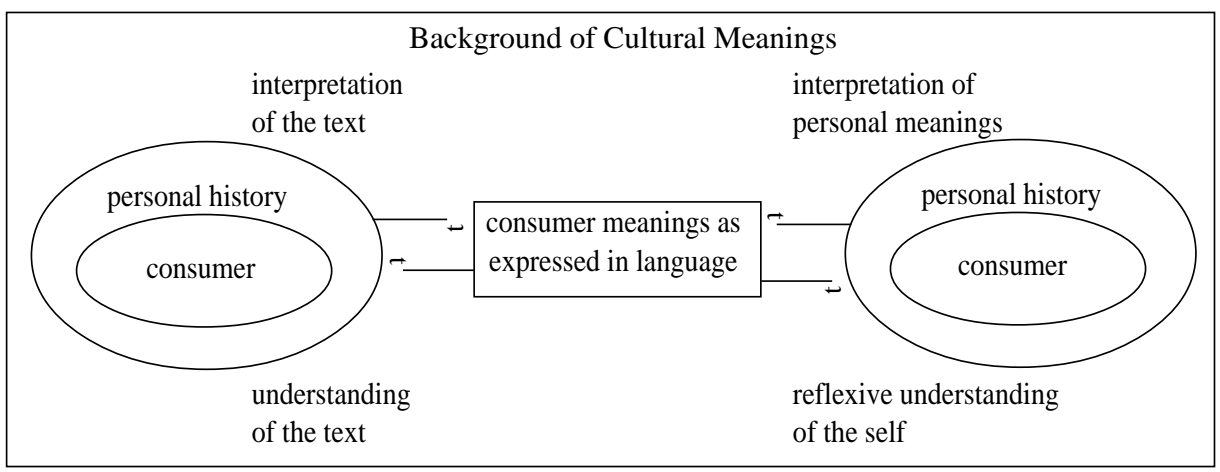

Source: Thompson et al. (1994: 434) 
Table 4. Positivism versus Interpretivism

\begin{tabular}{|c|c|c|}
\hline Assumptions & Positivism & Interpretivism \\
\hline \multicolumn{3}{|l|}{$\overline{\text { Ontological assumptions }}$} \\
\hline Nature of reality & $\begin{array}{l}\text { objective, tangible } \\
\text { single } \\
\text { fragmentable } \\
\text { divisible }\end{array}$ & $\begin{array}{l}\text { socially constructed } \\
\text { multiple } \\
\text { holistic } \\
\text { contextual }\end{array}$ \\
\hline Nature of social beings & $\begin{array}{l}\text { deterministic } \\
\text { reactive }\end{array}$ & $\begin{array}{l}\text { voluntaristic } \\
\text { proactive }\end{array}$ \\
\hline \multicolumn{3}{|l|}{ Axiological assumptions: } \\
\hline Overriding goal & $\begin{array}{l}\text { "explanation" via } \\
\text { subsumption under } \\
\text { general laws, prediction }\end{array}$ & $\begin{array}{l}\text { "understanding" based on } \\
\text { verstehen }\end{array}$ \\
\hline \multicolumn{3}{|l|}{$\begin{array}{l}\text { Epistemological } \\
\text { assumptions: }\end{array}$} \\
\hline Knowledge generated & $\begin{array}{l}\text { nomothetic } \\
\text { time- free } \\
\text { context-independent }\end{array}$ & $\begin{array}{l}\text { idiographic } \\
\text { time-bound } \\
\text { context-dependent }\end{array}$ \\
\hline View of causality & real causes exist & $\begin{array}{l}\text { multiple, simultaneous } \\
\text { shaping }\end{array}$ \\
\hline Research relationship & $\begin{array}{l}\text { dualism, separation } \\
\text { previlege } 4 d \text { point of } \\
\text { observation }\end{array}$ & $\begin{array}{l}\text { interactive, cooperative } \\
\text { no previleged point of } \\
\text { observation }\end{array}$ \\
\hline
\end{tabular}

Source: Hudson and Ozanne (1988: 509)

The central concept of hermeneutic paradigm is the 'hermeneutical circle', that is, a multidimensional concept that addresses issues related to the culturally based nature of human understanding. Furthermore, there are three meanings of the hermeneutical circle. The first meaning refers to the methodological process for interpreting qualitative data. The process is an iterative process. The second meaning places that scientific knowledge is based on assumptions and beliefs from a culturally situated perspective. The third meaning refers to the interplay between those meanings handed down by cultural tradition and the personal meanings that individuals construct from them (Thompson et al. 1994) (see Figure 2).

Several consumer behavior studies on interpretative approach can be pointed out. For example, Hirschman's research in 1988 used the approach to understand consumption ideology. Another example is Thompson (1997) that used a hermeneutic framework for interpreting the stories consumers tell about their experiences of products, services, shopping, and others. The differences between positivist and interpretive approaches are presented in Table 4. 


\section{Historical Method}

The marketing and consumer behavior scholars have given little attention to historical research in marketing and consumer behavior (Smith and Lux 1993; Savitt 1980). According to Savitt (1980), there are two major reasons for the absence of historical research in marketing and consumer behavior: (1) the lack of appreciation in historical paradigm, and (2) the lack of understanding the historical methodology. On the other hand, Savitt pointed out that this paradigm proposes an alternative way and an alternative method to understanding marketing and consumer behavior disciplines, especially in understanding the origin, the past, and the changes of marketing and consumer behavior.

Historical method is basically descriptive. It uses an interpretive approach to investigate the causal motors that drive change through time. The empirical material is also needed for analyzing history. The method often uses retrodiction to at- tempt what might have happened in the past. The conceptual model of historical method with two stages is proposed by Smith and Lux (1993) as represented in Figure 3. The first stage is research design that contains research questions and research procedures. The second stage consists of three approaches, they are, investigation, synthesis, and interpretation. In addition, readers who are interested in a complete description of the historical method can refer to Golder (2000) as a guide when applying this method.

One example of marketing research that uses historical method is the study of Fullerton (1988). Fullerton did a research in marketing history in three countries: Britain, Germany, and the United States in the period of 1870 until 1930. His research proposed a new marketing evolution model that is different with other models in the marketing textbooks. Many marketing textbooks present that the marketing evolution started from the production era $\neq$ the sales era $\neq$ the marketing era. On the other hand, Fullerton stated that the marketing

Figure 3. Conceptual Model of Historical Method

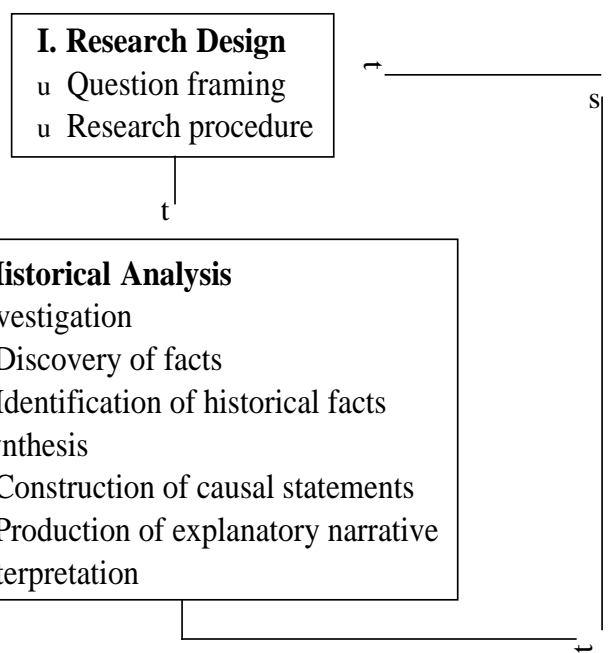

Source: Smith and Lux (1993: 600)

\begin{tabular}{|l|}
\hline II. Historical Analysis \\
u Investigation \\
Discovery of facts \\
Identification of historical facts \\
u Synthesis \\
Construction of causal statements \\
Production of explanatory narrative \\
u Interpretation
\end{tabular}


GadjahMadaInternationalJournal ofBusiness,May2002, Vol.4,No.2

evolution begins from the era of antecedents $\neq$ the era of origins $\neq$ the era of institutional development $\neq$ the era of refinement and formalization.

\section{Phenomenology}

According to Bertens (1987), phenomenology approach was born as reaction to positivism, that is, paradigm that emphasizes on scientific method. Phenomenology focuses on meanings. In other words, phenomenologists view people as creatures who give meaning. Therefore, language plays important role in this approach. The importance of language is presented by Bertens (1987: 64, emphasis as original) as follows:
Phenomenology pointed out that human is language in a specific term. Whatever humankind does or whatever humankind does not do, they express meanings with their actions.

Many psychology scientists, especially in psychoanalytic studies, are often using phenomenology method, for example Sigmund Freud. The primary aim of the method is to reach and grasp the essences of things appearing in consciousness (Misiak and Sexton 1973). That goal can be achieved by using three phases of the phenomenological approach, that is, phenomenological intuiting, analyzing, and describing (Spiegelberg 1971, cited by Misiak and Sexton 1973). Moreover, Misiak and Sexton (p. 7) also pointed out

Table 5. Positivism versus Phenomenological Paradigm

\begin{tabular}{|c|c|c|}
\hline & Positivism & Phenomenological Paradigm \\
\hline \multirow[t]{3}{*}{ Basic beliefs: } & $\begin{array}{l}\text { The world is external and } \\
\text { objective }\end{array}$ & $\begin{array}{l}\text { The world is socially cons- } \\
\text { tructed and subjective }\end{array}$ \\
\hline & Observer is independent & $\begin{array}{l}\text { Observer is part of what ob- } \\
\text { served }\end{array}$ \\
\hline & Science is value-free & $\begin{array}{l}\text { Science is driven by human in- } \\
\text { terests }\end{array}$ \\
\hline \multirow[t]{4}{*}{ Researcher should: } & Focus on facts & Focus on meanings \\
\hline & $\begin{array}{l}\text { Look for causality and } \\
\text { fundamental laws }\end{array}$ & $\begin{array}{l}\text { Try to understand what is hap- } \\
\text { pening }\end{array}$ \\
\hline & $\begin{array}{l}\text { Reduce phenomena to simplest } \\
\text { elements }\end{array}$ & $\begin{array}{l}\text { Look at the totality of each situ- } \\
\text { ation }\end{array}$ \\
\hline & $\begin{array}{l}\text { Formulate hypotheses and then } \\
\text { test them }\end{array}$ & $\begin{array}{l}\text { Develop ideas through in- } \\
\text { duction from data }\end{array}$ \\
\hline \multirow[t]{2}{*}{$\begin{array}{l}\text { Preferred methods } \\
\text { include: }\end{array}$} & $\begin{array}{l}\text { Operationalizing concepts so } \\
\text { that they can be measured }\end{array}$ & $\begin{array}{l}\text { Using multiple methods to es- } \\
\text { tablish different views of phe- } \\
\text { nomena }\end{array}$ \\
\hline & Taking large samples & $\begin{array}{l}\text { Small samples investigated in } \\
\text { depth or over time }\end{array}$ \\
\hline
\end{tabular}

Source: Easterby et al. (1991: 27) 
Oktoria Sihombing_Paradigms in Consumer Behavior

Table 6. Questions of Reliability, Validity, and Generalizability (Positivism versus Phenomenological Paradigm)

\begin{tabular}{|c|c|c|}
\hline & Positivism & Phenomenological Paradigm \\
\hline Validity & $\begin{array}{l}\text { Does an instrument measure } \\
\text { what is supposed to measure? }\end{array}$ & $\begin{array}{l}\text { Has the researcher gained full } \\
\text { access to the knowledge and } \\
\text { meanings of informants? }\end{array}$ \\
\hline Reliability & $\begin{array}{l}\text { Will the measure yield the same } \\
\text { results on different occasions } \\
\text { (assuming no real change in } \\
\text { what is to be measured)? }\end{array}$ & $\begin{array}{l}\text { Will similar observations be } \\
\text { made by different researchers } \\
\text { on different occasions? }\end{array}$ \\
\hline Generalizability & $\begin{array}{l}\text { What is the probability that } \\
\text { pattern observed in a sample } \\
\text { will also be present in the wider } \\
\text { population from which the } \\
\text { sample is drawn? }\end{array}$ & $\begin{array}{l}\text { How likely is it that ideas and } \\
\text { theories generated in one setting } \\
\text { will also apply in other settings? }\end{array}$ \\
\hline
\end{tabular}

Source: Easterby et al. (1991: 41)

that another step in that method is called Wesensschau, that is, an institution of essences, insight into essences, experience or cognition of essences. Table 5 and 6 present differences between positivism and phenomenology paradigm in terms of assumptions, reliability, validity, and generalizability.

\section{Existentialism}

Existentialism reacted against rationalism, positivism, materialism, and pragmatism. It opposed to those paradigms because existentialists directed their attention not to the essence of things, but to the existence. Essence is something that makes things what they are. Essence is also a central concept for phenomenologist. However, existentialists defined existence in accordance with the etymology of this word. Existence means to stand out, to become, or to emerge. Therefore, man is not viewed as static being, but continually changing and developing. Related to methodological approach, all existential- ists have accepted the phenomenological approach as a basic and valid method. In this sense, it can be stated that existentialists are phenomenologists, not vice versa (Misiak and Sexton 1973: 69).

\section{Existential - Phenomenological}

Existential-phenomenological paradigm is a paradigm that combines the philosophy of existentialism and the methods of phenomenology. The paradigm aims to describe the totality of human being in the world by focusing on the life-world of the individual. In particular, the purpose of the paradigm is to describe human experience as it is lived as both reflected and unreflected (Thompson 1989).

The interview is the most powerful method to obtain in-depth understanding of people experiences. There are several steps that should be taken in implementing the interview: (1) developing the interview format, (2) determining the interview context, (3) avoiding 'why' questions, because those questions can be per- 
Table 7. Existential-Phenomenological Characteristics

\begin{tabular}{ll}
\hline World view & : contextual \\
Nature-of-being & $:$ in-the-world \\
Research focus & : experience \\
Research perspective: & first-person \\
Research logic & $:$ apodictic \\
Research strategy & $:$ holistic \\
Research goal & $:$ thematic descrip- \\
& tion \\
\hline
\end{tabular}

Source: Thompson (1989: 137)

ceived as requests for rationalization and can engender defensive responses, and (4) attaining a phenomenological dialogue. The next phase after interview is the interpretation phase that uses three criteria of phenomenological interpretation: (1) the emic approach, (2) the autonomy of the text, and (3) bracketing (Thompson 1989). Table 7 shows a summary of existentialphenomenological approach to consumer research.

\section{Critical Theory}

Critical theory was one of dominant philosophy in twentieth century (Suseno 1992). This theory is an interdisciplinary perspective that critizes social conditions and aims to help people envision a better society, that is, it aims to release constraints on human freedom and potential (Murray and Ozanne 1991).

Critical theory is developed out of two general periods. The first period began in 1923 with the founding of Institut fur Sozialforschung in Frankfurt, which was known as Frankfurt school of thought. The second period began with Jurgen Habermas's remolding of critical theory and continues to the present (Murray and Ozanne 1991). The major characteristic of the theory, which is different to other paradigm, is the theory itself not as perspective only and far from the real world (Suseno 1992). However, critical theory is a practical theory (Fleming 1997; Murray and Ozanne 1991).

Furthermore, Suseno stated that critical theory views itself as the theory that carries Karl Max' aspirations, that is, to be emancipator theory in order to free people from all forms of domination. Suseno also added that critical theory is a critique movement in human thought processes that does not judge other theories, but "let those theories in their songs" (p. 180). In other words, the principle of the theory is to face the theory with its aim, therefore (if there are) lies and false will be revealed by it.

In terms of research methodology, there are three stages in a critical research: initial stage, data collection stage, and evaluative stage (Table 8). In the initial stage, critical theory tries to identify a concrete practical problem. After a practical problem is selected, then all groups or individuals who are involved with the problem are identified. Then, there is five steps include in data collection stage: (1) the interpretive step, (2) the historical-empirical step, (3) the dialectical step, (4) the awareness step, and (5) the praxis step. In the final stage (i.e., evaluative stage), evaluative criterias exist for each of the five steps in the data collection process (Table 9). For instance, the researcher must form an understanding based on the perceptions of all the people involved. Another example, the researcher must understand how social conditions are historically grounded in the historical-empirical step (Murray and Ozanne 1991). 
Oktoria Sihombing_Paradigms in Consumer Behavior

Table 8. Methodological Approach (Positivism versus Critical Theory)

\begin{tabular}{|c|c|c|}
\hline Research Process & Positivism & Critical Theory \\
\hline \multirow[t]{2}{*}{ Initial stages } & $\begin{array}{l}\text { Review of existing li- } \\
\text { terature to identify a gap }\end{array}$ & $\begin{array}{l}\text { Identification of a concrete } \\
\text { practical problem }\end{array}$ \\
\hline & $\begin{array}{l}\text { Development of an a } \\
\text { priori conceptual frame- } \\
\text { work }\end{array}$ & $\begin{array}{l}\text { Identification of all groups in- } \\
\text { volved with this problem }\end{array}$ \\
\hline \multirow[t]{5}{*}{$\begin{array}{l}\text { Data collection stage: } \\
\text { General structure }\end{array}$} & $\begin{array}{l}\text { Empirical testable hypo- } \\
\text { theses are derived from } \\
\text { the conceptual frame- } \\
\text { work }\end{array}$ & $\begin{array}{l}\text { The interpretative step: } \\
\text { construction of an intersubjective } \\
\text { understanding of each group }\end{array}$ \\
\hline & $\begin{array}{l}\text { Hypotheses are tested in } \\
\text { a fixed design }\end{array}$ & $\begin{array}{l}\text { The historical-empirical step: } \\
\text { examination of the historical } \\
\text { development of any relevant } \\
\text { social structures or procesess }\end{array}$ \\
\hline & Data are gathered & $\begin{array}{l}\text { The dialectical step: } \\
\text { search for contradiction between } \\
\text { the intersubjective understanding } \\
\text { and the objective social conditions }\end{array}$ \\
\hline & $\begin{array}{l}\text { Strict adherence to } \\
\text { scientific protocol }\end{array}$ & $\begin{array}{l}\text { The awareness step: } \\
\text { discuss alternative ways of seeing } \\
\text { their situation with the repressed } \\
\text { group(s) }\end{array}$ \\
\hline & $\begin{array}{l}\text { Statistical analysis of } \\
\text { data to yield an explana- } \\
\text { tion }\end{array}$ & $\begin{array}{l}\text { The praxis step: } \\
\text { participate in a theoretically } \\
\text { grounded program of action to } \\
\text { change social conditions }\end{array}$ \\
\hline $\begin{array}{l}\text { Standard data-gathering } \\
\text { techniques }\end{array}$ & $\begin{array}{l}\text { Laboratory experiment } \\
\text { Large-scale survey }\end{array}$ & $\begin{array}{l}\text { In-depth interviews } \\
\text { Historical analysis }\end{array}$ \\
\hline $\begin{array}{l}\text { Sample evaluative } \\
\text { criteria }\end{array}$ & Validity and realibility & Improvement of quality of life \\
\hline
\end{tabular}

Sorce: Murray and Ozanne (1991: 136) 
GadjahMadaInternationalJournal of Business,May2002, Vol.4,No.2

Tabel 9. Evaluative Criteria for Each Data Collection Step

\begin{tabular}{|c|c|}
\hline Data Collection Step & Evaluative Criteria \\
\hline Interpretive step & $\begin{array}{l}\text { Where all relevant social groups identified? } \\
\text { Did the researcher's understanding evolve as more was learned? } \\
\text { Did the researcher see the situation in the same way as the social } \\
\text { actors (using their language and concepts)?) } \\
\text { Is the understanding based on the meanings and values of the } \\
\text { people who are involved? } \\
\text { Are the intersubjective understanding grounded historically? } \\
\text { Did the searcher employ a dialogical, hermeneutical method? } \\
\text { Is the account coherent and complete? }\end{array}$ \\
\hline Historical-empirical step & $\begin{array}{l}\text { Are all relevant social processes and structures identified? } \\
\text { Have all relevant empirical studies been examined? Were new } \\
\text { studies initiated to fill in any gaps? } \\
\text { Is the understanding of the social conditions historically grounded? } \\
\text { Has the analysis focused on the historical totality? } \\
\text { Is the social contractedness of reality transparent? }\end{array}$ \\
\hline Dialectical step & $\begin{array}{l}\text { Do we understand the dynamic relationship between the social } \\
\text { conditions and the intersubjective understandings? } \\
\text { Are the interests of the various group known? } \\
\text { Are all contradictions and internal inconsistencies identified? } \\
\text { Are the intersubjective understandings linked to the social condi- } \\
\text { tions that maintain them? } \\
\text { Are the injured groups identified? }\end{array}$ \\
\hline Awareness step & $\begin{array}{l}\text { Do the social actors see their current situation accurately? } \\
\text { Are social actors aware of unrecognized social constraints and do } \\
\text { they see how the conditions came to exist? } \\
\text { Is awareness achieved through dialogue? } \\
\text { Are the social actors involved? } \\
\text { Are new alternative courses of action presented? } \\
\text { Do social actors see themselves as capable of positive action? } \\
\text { Do the social actors choose their course of action? }\end{array}$ \\
\hline Praxis step & $\begin{array}{l}\text { Has the contradiction been resolved? } \\
\text { Are the participants' subjective images formed into objective } \\
\text { structures? } \\
\text { Are social conditions changed to be less constraining? } \\
\text { Is the political action effective? Is life made better? } \\
\text { Is some ongoing program initiated to continue the critical process? }\end{array}$ \\
\hline
\end{tabular}

Source: Murray and Ozanne (1991: 139) 
In a consumer-research context, the results of critical theory give contribution to academic, public, and private interests. For academic interests, the theory can be used to understand the 'dark side' of consumer behavior, for instance: credit card abuse, drug addition, and others. For public constituency, the theory has potential to generate social change strategies that may useful for legislators or consumerrights organizations. For private interest, the theory provides a way to achieve competitive advantage without contradicting the public interest.

The comparison between critical theories with other paradigms can be presented in a perceptual map in Figure 4. There are two axes on the map: subjective-objective axis and conflict-order axis. The first axis, that is the subjective-objective axis, ex- plains about the nature of reality. In other words, subjectivism views that science creates multiple realities that are socially and experientially based. In contrast, objectivism holds that science discovers the true nature of reality. The second axis, that is the conflict-order axis, focuses on social changes which range from order to conflict stance. Critical theory, as seen in Cluster 3, holds the importance of both subjective and objective aspects of reality. Furthermore, as in conflict axis, critical theory aims at critiquing and transforming social, political, economics, cultural and others in order to improve the quality of life (Murray and Ozanne 1991). Table 10 further presents the differences between positivism and critical theory in relation with their aim and assumptions.

Figure 4. Perceptual Map of Approaches to Seeking Knowledge in Consumer Research

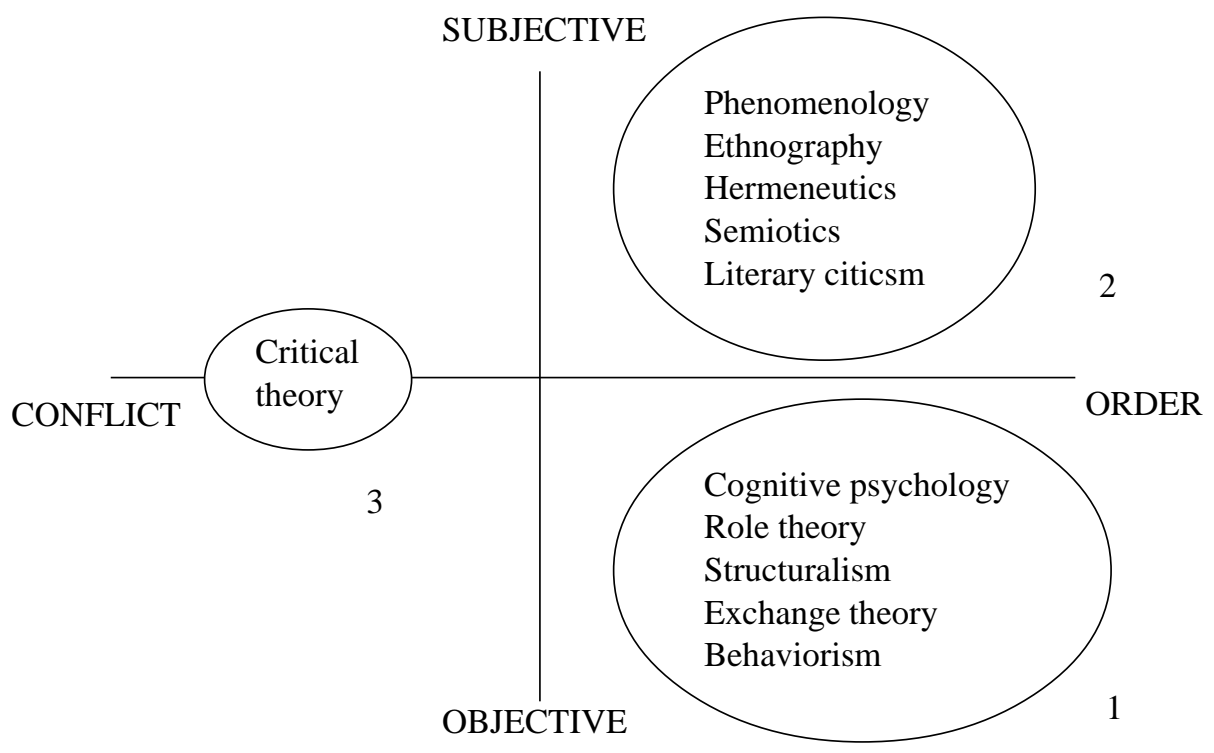

Source: Murray and Ozanne (1991: 130) 
GadjahMadaInternationalJournal of Business,May2002, Vol.4,No.2

Tabel 10. Positivism Versus Critical Theory Approaches

\begin{tabular}{|c|c|c|}
\hline Asumptions & Positivism & Critical theory \\
\hline \multicolumn{3}{|l|}{ Ontological assumptions } \\
\hline \multirow[t]{4}{*}{ Nature of reality } & Objective, tangible & $\begin{array}{l}\text { "Force-field" between subject and } \\
\text { object }\end{array}$ \\
\hline & Single, ahistorical; & \\
\hline & Fragmentable; & Dynamic; \\
\hline & Divisible & Historical totality \\
\hline \multirow[t]{2}{*}{ Nature of social beings } & Deterministics; & Suspend judgment; \\
\hline & Reactive & Emphasize human potential \\
\hline \multicolumn{3}{|l|}{ Nature of social beings } \\
\hline Overriding goal & $\begin{array}{l}\text { "Explanation" via sub- } \\
\text { sumption }\end{array}$ & $\begin{array}{l}\text { "Emancipation" via social orga- } \\
\text { zation that facilitates reason, } \\
\text { justice, and freedom }\end{array}$ \\
\hline \multicolumn{3}{|c|}{ Epistemological assumptions } \\
\hline Knowledge generated & Nomothetic; & Forward-looking; \\
\hline \multirow[t]{3}{*}{ Axiological assumptions } & Time-free; & Imaginative; \\
\hline & Context-independent; & Critical/unmasking \\
\hline & Value-free & Practical \\
\hline View of causality & Reak causes exist & $\begin{array}{l}\text { Reflection, exposure of constraint } \\
\text { through dialogue, reconstruc } \\
\text { tion, reflection }\end{array}$ \\
\hline Research relationship & Dualism, separation & Continuing dialogue \\
\hline Metaphor & Detached observer & Liberator \\
\hline
\end{tabular}

Source : Murray and Ozanne (1991: 133)

\section{Humanistic}

Hirschman (1986 cited by Sheth et al. 1988: 185) pointed out that humanistic approach is an important approach in consumer behavior studies. According to her, consumer behavior studies need humanistic modes of inquiry because they advocate more naturalistic forms of inquiry as she stated as follows (see also Table 11):

...it advocates in-dwelling of the researcher with the phenomena under investigation. Rather than standing apart from the system being studied, the re- searcher immerses the self within it. Researcher understanding, therefore, is deemed within the humanistic perspective to arise from direct personal experience, rather than by the manipulation of experimental variables.

One example of method used in humanistic approach is idiographic method, which introduced by Allport in 1937. The method is useful to understand individual. However, logical positivistics reject that method because the result of the research cannot be generalized. Still, that method proposed by Allport gives new motivation 
Oktoria Sihombing_Paradigms in Consumer Behavior

Table 11. Positivism versus Humanism

\begin{tabular}{lll}
\hline \multicolumn{1}{c}{ Positivism } & & \multicolumn{1}{c}{ Humanism } \\
$\begin{array}{lll}\text { There is a single reality composed of } \\
\text { discrete elements }\end{array}$ & & Human beings construct multiple realities \\
$\begin{array}{l}\text { The researcher and the phenomenon are } \\
\text { independent }\end{array}$ & $\begin{array}{l}\text { Researcher and phenomenon are mutually } \\
\text { interactive }\end{array}$ \\
$\begin{array}{l}\text { It is possible and desirable to develop } \\
\text { statements of truth that are generalizable } \\
\text { across time and context }\end{array}$ & $\begin{array}{l}\text { Research inquiry is directed toward the } \\
\text { development of idiographic knowledge }\end{array}$ \\
$\begin{array}{l}\text { Elements of reality can be segregated into } \\
\text { causes and effects }\end{array}$ & $\begin{array}{l}\text { Phenomenal aspects cannot be segregated } \\
\text { into "causes and effects" }\end{array}$ \\
$\begin{array}{l}\text { It is possible and desirable to discover } \\
\text { value-free objective knowledge }\end{array}$ & Inquiry is inherently value-laden \\
\hline
\end{tabular}

Source: Hirschman (1986, quoted by Sheth et al. 1988: 186)

to the development of consumer behavior analytical tools (Jaccard and Dittus 1990).

Beside idiographic method, humanistic inquiry uses literary criticism to understand consumer behavior. For example, Stern's study in 1989 used literary criticism to analyze the literary aspects of advertising texts in order to understand consumer, because ads simultaneously reflect and influence consumer. Literary criticism is often used in advertisement research (see also Stern and Schroder 1993a, 1993b). Readers who interested in literary criticism can refer to Stern (1989) for methodological approach.

\section{Ethnographic Method}

Ethnography is the art and science of describing a group or culture (Fetterman 1989: 11). In detail, ethnography has characteristics as follows: (1) holistic perspective, (2) contextual, (3) emic perspective (i.e., the ethnographer describes a social scene from insider's perspective), (4) ethic perspective (i.e., is the external, social scientific perspective on reality), and (5) nonjudgmental orientation (Fetterman 1989).

Fetterman also pointed out that an ethnographic approach may also be characterized as on in which the investigation seeks to (1) obtain a close-up and thick description of the phenomena of interest, (2) challenge the logical positivists by showing that all evidence is relative and dependent of the investigator, and (3) encourage long periods and unstructured fieldwork in order to obtain regularities of everyday life.

According to Yin (1993), ethnographic research does not necessarily begin with theoretical foundations. The research focuses on shared beliefs, practices, artifacts, and behaviors of people in the phenomena of interest. The usual objective of this type of research is theory building rather than theory testing. Furthermore, the outcome of study is thick description of the phenomenon. Table 12 shows the different assumptions between ethnographic method and positivist method (i.e. quasi-experiment) 
GadjahMadaInternationalJournal ofBusiness,May2002, Vol.4,No.2

Table 12. The Different Assumptions of Ethnographic and Positivist Methods

\begin{tabular}{|c|c|c|}
\hline & Types of 1 & thod \\
\hline & Ethnographic & Quasi-experiment \\
\hline Design: & & \\
\hline $\begin{array}{l}\text { Assumes a single } \\
\text { objectivity reality that } \\
\text { can be investigated by } \\
\text { following the traditional } \\
\text { scientific inquiry }\end{array}$ & no & yes \\
\hline $\begin{array}{l}\text { Can be used for theory- } \\
\text { building }\end{array}$ & yes & yes \\
\hline Also favors theory-testing & no & yes \\
\hline $\begin{array}{l}\text { Considers context as } \\
\text { essential part of phenomenon } \\
\text { of being evaluated }\end{array}$ & yes & no \\
\hline $\begin{array}{l}\text { Data colection and analysis: } \\
\text { Favored data collection } \\
\text { technique }\end{array}$ & participant observation & multiple \\
\hline Type of data to be analyzed & mostly qualitative & mostly quantitative \\
\hline
\end{tabular}

Source: Yin (1993: 64)

In a research, positivism uses the procedure that analysis follows data collection. In contrast, in ethnographic research, analysis and data collection begins simultaneously (Fetterman 1989). Furthermore, ethnographic interpretation is constructed from two major data sources: behavior observation and verbal reports (Arnould and Wallendorf 1994). Therefore, this type of research takes long periods and the researcher should participate in the phenomena of study. The researcher's participation is known as go native (Wilardjo 1986). Wilardjo also stated that the main advantage of ethnographic research is the thick description of the study even though the result cannot be generalized.
An example of ethnographic study in marketing field is the research conducted by Arnould and Wallendorf in 1994. Those researchers pointed out that ethnographic can provide multiple strategically important insights on consumer behaviors, which are useful for marketers. Other examples are research on consumer consumption on thanks-giving day (cited by Arnould dan Wallendorf 1994) and research on advertisement (Ritson and Richard 1999).

\section{Summary}

This section will present summary of all discussion on quantitative and qualitative paradigm. This section will show the brief description on ontology, epistemol- 
Oktoria Sihombing_Paradigms in Consumer Behavior

Table 13. Major Characteristics of Subjective-Objective Approaches

\begin{tabular}{|c|c|c|c|c|c|c|}
\hline \multirow[b]{2}{*}{$\begin{array}{l}\text { Core ontological } \\
\text { assumptions }\end{array}$} & \multicolumn{3}{|c|}{$\begin{array}{l}\text { Subjectivist approaches } \\
\text { to social science }\end{array}$} & \multicolumn{3}{|c|}{$\begin{array}{l}\text { Objectivist approaches } \\
\text { to social science }\end{array}$} \\
\hline & $\begin{array}{l}\text { Reality as a } \\
\text { projection } \\
\text { of human } \\
\text { imagination }\end{array}$ & $\begin{array}{l}\text { Reality as a } \\
\text { social } \\
\text { construction }\end{array}$ & $\begin{array}{l}\text { Reality as a } \\
\text { realm of } \\
\text { symbolic } \\
\text { discourse }\end{array}$ & $\begin{array}{c}\text { Reality as a } \\
\text { contextual } \\
\text { field of } \\
\text { information }\end{array}$ & $\begin{array}{c}\text { Reality as a } \\
\text { concrete } \\
\text { process }\end{array}$ & $\begin{array}{l}\text { Reality as a } \\
\text { concrete } \\
\text { structure }\end{array}$ \\
\hline $\begin{array}{l}\text { Assumptions } \\
\text { about human } \\
\text { nature }\end{array}$ & $\begin{array}{l}\text { Man as pure } \\
\text { spirit, } \\
\text { consciouness, } \\
\text { being }\end{array}$ & $\begin{array}{l}\text { Man as a } \\
\text { social } \\
\text { constructor, } \\
\text { the symbol } \\
\text { creator }\end{array}$ & $\begin{array}{l}\text { Man as an } \\
\text { actor, the } \\
\text { symbol } \\
\text { user }\end{array}$ & $\begin{array}{c}\text { Man as an } \\
\text { information } \\
\text { process }\end{array}$ & $\begin{array}{l}\text { Man as an } \\
\text { adaptor }\end{array}$ & $\begin{array}{l}\text { Man as a } \\
\text { responder }\end{array}$ \\
\hline $\begin{array}{l}\text { Basic epistemo- } \\
\text { logical stance }\end{array}$ & $\begin{array}{l}\text { To obtain phe- } \\
\text { nomenologi- } \\
\text { cal insight, } \\
\text { revelation }\end{array}$ & $\begin{array}{l}\text { To under- } \\
\text { stand how } \\
\text { social } \\
\text { reality is } \\
\text { created }\end{array}$ & $\begin{array}{l}\text { To understand } \\
\text { patterns } \\
\text { of symbolic } \\
\text { discourse }\end{array}$ & $\begin{array}{l}\text { To map } \\
\text { contexts }\end{array}$ & $\begin{array}{l}\text { To study } \\
\text { systems, } \\
\text { process, } \\
\text { change }\end{array}$ & $\begin{array}{l}\text { To construct } \\
\text { a positivist } \\
\text { science }\end{array}$ \\
\hline $\begin{array}{l}\text { Some favored } \\
\text { metaphors }\end{array}$ & $\begin{array}{l}\text { Trancenden- } \\
\text { tal }\end{array}$ & $\begin{array}{l}\text { Language } \\
\text { game, } \\
\text { accomplish- } \\
\text { ment, text }\end{array}$ & $\begin{array}{l}\text { Theater, } \\
\text { culture }\end{array}$ & Cybernetic & Organism & Machine \\
\hline $\begin{array}{l}\text { Research } \\
\text { methods }\end{array}$ & $\begin{array}{c}\text { Exploration of } \\
\text { pure } \\
\text { subjectivity }\end{array}$ & Hermeneutics & $\begin{array}{l}\text { Symbolic } \\
\text { analysis }\end{array}$ & $\begin{array}{l}\text { Contextual } \\
\text { analysis } \\
\text { of Gelstat }\end{array}$ & $\begin{array}{l}\text { Historical } \\
\text { analysis }\end{array}$ & $\begin{array}{l}\text { Lab experi- } \\
\text { ments, } \\
\text { surveys }\end{array}$ \\
\hline
\end{tabular}

Source: Morgan and Smirich (1980: 492)

ogy, and human nature of each paradigm as in Table 13. Table 13 shows that paradigms can be constructed in a continuum. For example, radical subjectivist is based on subjectivity approach that views reality as a projection of human imagination. In addition, radical humanism prefers exploration of pure subjectivity as a research method. On the other side, radical objectivist views reality as a concrete structure and uses lab experiment or survey to understand the reality.

\section{The Importance of Reconciliation between Quantitative and Qualitative Paradigm}

Several paradigms and their methodologies have been presented in this article. Assessment on positivism and the comparison between positivism and nonpositivism have been also pointed out. Furthermore, the choice on the appropriate paradigm in marketing and consumer 
behavior depends on the readers' perspective. However, the reconciliation or the rapprochement between quantitative and qualitative paradigms is important toward the development of consumer behavior science (Heath 1992; Deshpande 1983; Evered and Louis 1981).

Deshpande (1983) stated that the dominance of one paradigm (i.e., logical empiricism) in marketing and consumer behavior is unfortunate since the domination only support in the area of hypothesis testing rather that developing new theory. Therefore, he pointed out two major directions to solve the problem. First, he stated that qualitative methods could be used to generate new theories. Then, quantitative methods are useful for theory testing. Therefore, the contributions from a set of methodologies can cover all aspects such as theory confirmation, research design, and data analysis.
In addition, Evered and Louis (1981) also pointed out that the combination between quantitative and qualitative paradigms is needed. According to them, researchers should explore ways of combining them, with the aim of securing the strengths of each and avoiding their respective deficiencies (Figure 5).

On the other hand, Hunt (1991b) proposed an alternative paradigm, which he called as 'critical pluralism', that is, a paradigm, which guides researchers, to view their own, and others' theories and methods by adopting a tolerant posture toward new theories. However, this alternative paradigm also requires standards. The standard is needed to assess research trustworthiness. Wallendorf and Belk (1989, cited by Hunt 1991b: 41) pointed out that any research approach requires standards to assess its trustworthiness (i.e., the credibility, transferability, dependabil-

\section{Figure 5. Linking the Inquiry from the Outside and Inside}

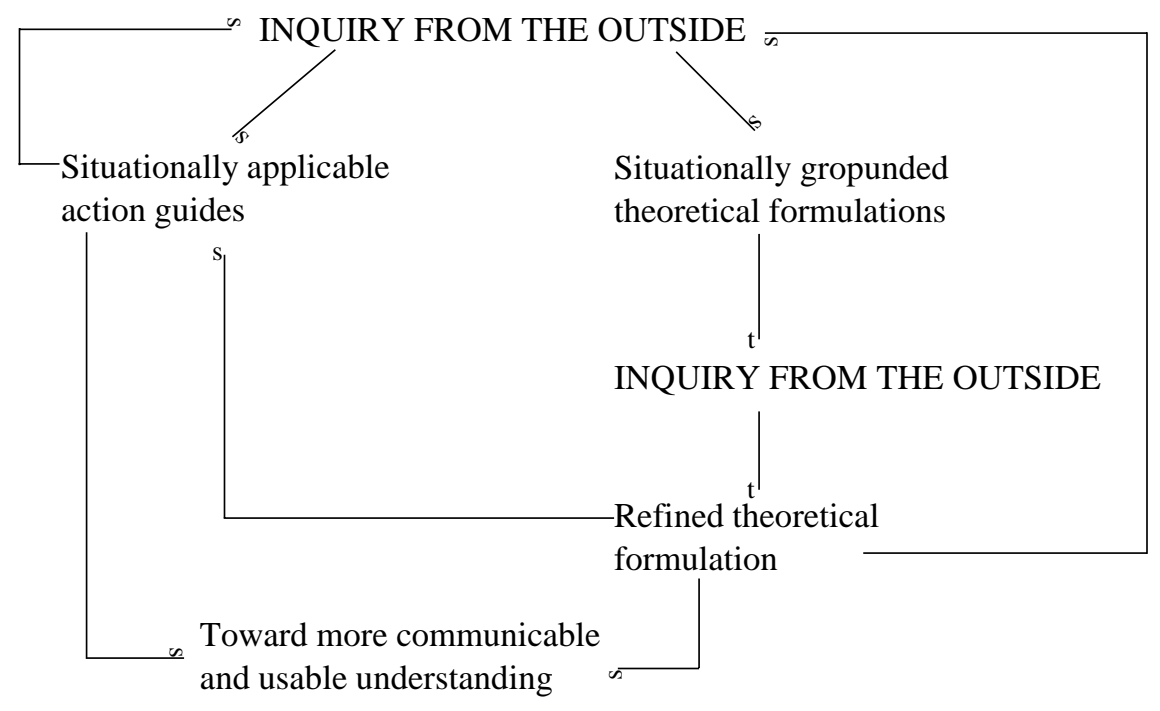

Source: Evered and Louis (1981: 393) 
Table 13. Features, Beliefs, and Interests Shared by Positivist and Nonpositivist

\begin{tabular}{ll} 
1. & Multiple and valid data interpretations (realities) \\
2. & Credibility (validity) \\
3. & Transferability (generalizability and replication) \\
4. & Reliability (dependability) \\
5. & Confirmability (objectivity) \\
6. & Apparent differential validities of interpretations (realities) \\
7. & Subject honesty (integrity) \\
8. & Peer review \\
9. & Description \\
10. & Causation (influences and process) \\
11. & Context effects \\
12. & Researcher effects \\
13. & Level of analysis that are gestalt to some but elements to others \\
14. & Stratified (purposive) sampling \\
15. & Exploratory research \\
16. & Emergent research \\
17. & Hypothesis (expectation) assessments \\
18. & Qualitative data \\
19. & Quantitative data \\
20. & Induction \\
21. & Deduction \\
22. & Triangulation (convergence procedures) \\
\hline
\end{tabular}

Source: Heath (1992, p. 116)

ity, and confirmability), the importance of which is postulated to be a scientific universal.

Another researcher, Heath (1992), also pointed out the need of the reconciliation. In relation with Kuhn's concept on 'incommensurability paradigm', Heath stated that incommensurability paradigm is analogous with the term noncomparable. Therefore, according to him, the debate on commensurability rests on semantics. For example, when consumers face noncomparable alternatives, they can use more abstract criteria (e.g., overall value) to choose one of those alternatives. Therefore, he pointed out that the reconciliation would be achieved more easily in practice than in institutional philosophy (p. 115). He also quoted Feyerabend (1987) who claimed that incommensurability is a problem for philosophers, not for scientist. In short, he stated that through compromise, researchers would achieve partial reconciliation on many dimensions such as presented in Table 13.

\section{Conclusion}

It is important to understand many paradigms and methodologies in both marketing and consumer behavior disciplines. That understanding will help researchers choose which method and methodology are appropriate for their studies. However, it is also important to reconcile both of quantitative and qualitative paradigms or using rapprochement. For example, Hunt (1991b) proposed rapproche- 
ment approach by suggesting 'critical pluralism', that is, an approach that requires us to adopt a tolerant, open posture toward new theories and methods. Critical pluralism also means that all methods and theories can (and must) be subjected to critical scrutiny. Therefore, a science of consumer behavior can be a critical, provocative, interesting, and creative science.

The position I take here is not that positivism should be abandoned but rather that many paradigms are needed. I agree with Ekelund and Hebert (1997), which pointed out, that the progress of science depends on the use and application of many paradigms and their methodologies. In other words, alternative ways of seeking knowledge should be sought. Furthermore, I also agree with Olson's suggestion that invite all of us to open our mind, release "you're-either-with-us-or-against- us" syndrome, and accept different perspectives in order to develop and to stimulate consumer behavior science as he stated as follows (1983: 403, emphasis added):

Let's not get into the kind of situations common in many of the disciplines from which we borrow - the "You're-eitherwith-us-or-against-us" syndrome. All types of researchers, with different perspectives and different preferred styles of inquiry, are necessary to develop a science of consumer behavior. We need the empirics, the humanist, and the theorist. We need people interested in data analysis, methodology, modeling, marketing, psychology, sociology, and philosophy. But, to make it all work, each person needs to understand the perspectives of the others and appreciate their contributions.

\section{References}

Arnold, S. J., and E. Fischer. 1994. Hermeneutics and consumer research. Journal of Consumer Research 21: 55-70.

Arnould, E. J., and M. Wallendorf. 1994. Market-oriented ethnography: Interpretation building and marketing strategy formulation. Journal of Marketing Research 31: 484-504.

Bertens, K. 1987. Panorama Filsafat Modern. Jakarta: PT. Gramedia.

Chalmers, A. F. 1983. Apa Itu Yang Dinamakan Ilmu. Jakarta: Hasta Mitra.

Delfgauw, B. 1988. Filsafat Abad 21. Yogyakarta: PT. Tiara Wacana.

Deshpande, R. 1983. Paradigma lost: On theory and method in research in marketing. Journal of Marketing 47: 101-110.

Easterby, S. M., R. Thorpe, and A. Lowe.1991. Management Research: An Introduction. London: Sage.

Ekelund, R. B., and R. F. Hebert. 1997. A History of Economic Theory and Method. New York: McGraw-Hill.

Epstein, S. 1996. Recommendation for the future development of personality psychology. Journal of Research in Personality 30: 435-446. 
Oktoria Sihombing_Paradigms in Consumer Behavior

Evered, R., and M. R. Louis. 1981. Alternative perspectives in the organization sciences: 'Inquiry from the inside' and 'Inquiry from the outside.' Academy of Management Review 6 (3): 385-395.

Fetterman, D. M. 1989. Ethnography: Step by Step. London: Sage.

Filstead, W. J. 1979. Qualitative methods: A needed perspective in evaluation research. In Qualitative and Quantitative Methods in Evaluation Research. Thomas D. Cook, and Charles S. Reichardt (eds.). California: Sage.

Fleming, M. 1997. Critical theory between modernity and post modernity. Philosophy Today 41: 31-39.

Fullerton, R. A. 1988. How modern is modern marketing? Marketing's evolution and the myth of the "Production Era." Journal of Marketing 52: 108-125.

Golder, P. N. 2000. Historical method in marketing research with new evidence on longterm market share stability. Journal of Marketing Research 37: 156-172.

Heath, T. B. 1992. The reconciliation of humanism and positivism in the practice of consumer research: A view from the trenches. Journal of the academy of marketing science 20: 107-118.

Hirschman, E. C. 1986. Humanistic inquiry in marketing research: Philosophy, method, and criteria. Journal of Marketing Research 23: 237-249.

Hirschman, E. C. 1988. The ideology of consumption: A structural-syntactical analysis of "Dallas" and "Dynasty." Journal of Consumer Research 15: 344-354.

Holbrokk, M. B., and J. O'Shaughnessy. 1988. On the scientific status of consumer research and the need for an interpretive approach to studying consumption behavior. Journal of Consumer Research 15: 398-402.

Holbrokk, M. B., and E. C. Hirschman. 1995. The experiential aspects of consumption: Consumer fantasies, feelings, and fun. In Marketing Classics ( $8^{\text {th }}$ eds.). Ben M. E., K. C. Keith, and M. P. Mokwa (eds.). New Jersey: Prentice-Hall.

Hudson, L. A., and J. L. Ozanne. 1988. Alternative ways of seeking knowledge in consumer research. Journal of Consumer Research 14: 508-521.

Hunth, S. D. 1991a. Modern Marketing Theory: Critical Issues in the Philosophy of Marketing Science. Ohio: South-Western Publishing.

1991b. Positivism and paradigm dominance in consumer research: Toward critical pluralism and rapprochement. Journal of Consumer Research 18: $32-44$.

1994. On rethinking marketing: Our discipline, our practice, our methods. European Journal of Marketing 28 (2): 13-25.

Jaccard, J., and P. Dittus. 1990. Idiographic and nomothetic perspectives on research methods and data analysis. In Research Methods in Personality and Social Psychology. Clyde H., and M. S. Clark (eds.). California: Sage. 
GadjahMadaInternationalJournal of Business,May2002, Vol.4,No.2

Kavanagh, D. 1994. Hunt versus Anderson: Round 16. European Journal of Marketing 28: $26-41$.

Kuhn, Th. 1962. The Structure of Scientifics Revolutions. Chicago: University of Chicago Press.

Levy, S. J. 1996. Stalking the amphisbaena. Journal of Consumer Research 23: 163-176.

Lynch, J. G. 1999. Theory and external validity. Journal of the Academy of Marketing Science 27: 367-376.

Suseno, F. M. 1992. Filsafat Sebagai Ilmu Kritis. Yogyakarta: Kanisius.

Misiak, H., and V. S. Sexton. 1973. Phenomenological, Existential, and Humanistic Psychologies. New York: Grune \& Stratton.

Morgan, G., and L. Smircich. 1980. The case for qualitative research. Academy of Management Review 5: 491-500.

Muncy, J. A., and R. P. Fisk. 1987. Cognitive relativism and the practice of marketing science. Journal of Marketing 51: 20-33.

Murray, J. B., and J. L. Ozanne. 1991. The critical imagination: Emancipatory interests in consumer research. Journal of Consumer Research 18: 129-144.

Nodoushani, O. 2000. Epistemological foundations of management theory and research methodology. Human Systems Management 19: 71-80.

Olson, J. C. 1983. Presidential address: 1981, toward a science of consumer behavior. In Marketing Theory: The Philosophy of Marketing Science. Shelby D. Hunt. Illinois: Richard D. Irwin.

Pervin, L. A. 1996. Personality: A view of the future based on a look at the past. Journal of Research in Personality 30: 309-318.

Peter, J. P. 1992. Realism or relativism for marketing theory and research: A comments on hunt's 'Scientific Realism.' Journal of Marketing 56: 72-79.

Peter, J. P. 1983. Some philosophical and methodological issues in consumer research. In Marketing Theory: The Philosophy of Marketing Science. Shelby D. Hunt. Illinois: Richard D. Irwin.

Ritson, M., and E. Richard. 1999. The social uses of advertising: An ethnographic study of adolescent advertising audiences. Journal of Consumer Research 26: 260-277.

Ritzer, G. 1992. Sosiologi : Ilmu Pengetahuan Berparadigma Ganda. Jakarta: Rajawali Press.

Sauer, W. J., N. Nighswonger, and G. Zaltman. 1983. Current issues in philosophy of science: Implications for the study of marketing. In Marketing Theory: The Philosophy of Marketing Science. Shelby D. Hunt. Illinois: Richard D. Irwin.

Savitt, R. 1980. Historical research in marketing. Journal of Marketing 44: 52-58.

174 
Oktoria Sihombing_Paradigms in Consumer Behavior

Sheth, J. N., D. M. Gardner, and G. E. Dennis. 1988. Marketing Theory : Evolution and Evaluation. New York: John Wiley \& Sons.

Siegel, H. 1988. Relativism for consumer research? (Comments on Anderson). Journal of Consumer Research 15: 129-132.

Smith, R. A., and D. S. Lux. 1993. Historical method in consumer research: Developing causal explanations of change. Journal of Consumer Research 19: 595-610.

Soeroso. 1984. Ilmuwan politik dan ilmu politik alternatif. Kompas (November 30).

Spiggle, S. 1994. Analysis and interpretation of qualitative data in consumer research. Journal of Consumer Research 21: 491-503.

Stern, B. B. 1989. Literary criticism and consumer research: Overview and illustrate analysis. Journal of Consumer Research 16: 322-334.

Stern, B. B. 1993. Feminist literary criticsm and the deconstruction of ads: A postmodern view of advertising and consumer responses. Journal of Consumer Research 19: 556-566.

Stern, B. B., and J. Schroeder. 1993. Interpretive methodology from art and library criticism: A humanistic approach to advertising imagery. European Journal of Marketing 28: 114-132.

Thompson, C. J. 1989. Putting consumer experience back into consumer research: The philosophy and method of existential-phenomenology. Journal of Consumer Research 16: 133-146.

1990. The lived meaning of free choice: An existential-phenomenological description of everyday consumer experiences of contemporary married women. Journal of Consumer Research 17: 346-361.

1997. Interpreting consumers: A hermeneutical framework for deriving marketing insights from the texts of consumers' consumption stories. Journal of Marketing Research 34: 438-455.

Thompson, C. J., P. R. Howard, and W. B. Locander. 1994. The spoken and the unspoken: A hermeneutic approach to understanding the cultural viewpoints that underlie consumers expresses meanings. Journal of Consumer Research 21: 433-452.

Wibisono, K. 1982. Arti Perkembangan: Menurut Filsafat Positivisme Auguste Comte. Yogyakarta: Gadjah Mada University Press.

Wilardjo, L. 1986. Menggusur dominasi logika-empirisme. In Ilmu dalam Perspektif Moral, Sosial, dan Politik: Sebuah Dialog Tentang Dunia Keilmuan Dewasa ini. Jujun S. Suriasumantri (ed.). Jakarta: PT. Gramedia.

Yin, R. K. 1989. Case Study Research: Design and Methods. London: Sage. 1993. Applications of Case Study Research. London: Sage. 